\title{
Article
}

\section{The Role of Brand Knowledge in Determining Sponsorship Effectiveness}

\author{
Donlan, Leah
}

Available at http://clok.uclan.ac.uk/4946/

Donlan, Leah ORCID: 0000-0002-1320-2803 (2013) The Role of Brand Knowledge in Determining Sponsorship Effectiveness. Journal of Promotion Management, 19 (2). pp. 241-264. ISSN 1049-6491

It is advisable to refer to the publisher's version if you intend to cite from the work. http://dx.doi.org/10.1080/10496491.2013.769474

For more information about UCLan's research in this area go to http://www.uclan.ac.uk/researchgroups/ and search for < name of research Group>.

For information about Research generally at UCLan please go to http://www.uclan.ac.uk/research/

All outputs in CLoK are protected by Intellectual Property Rights law, including Copyright law. Copyright, IPR and Moral Rights for the works on this site are retained by the individual authors and/or other copyright owners. Terms and conditions for use of this material are defined in the policies page.

\section{CLoK}

Central Lancashire online Knowledge www.clok.uclan.ac.uk

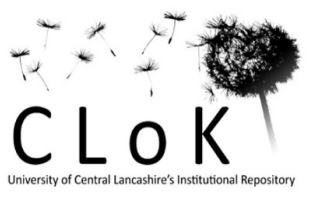


The Role of Brand Knowledge in Determining Sponsorship Effectiveness

Dr Leah Donlan*

University of Central Lancashire

School of Sport, Tourism and The Outdoors

Preston

Lancashire

PR1 2HE

United Kingdom

E-mail: LDonlan@uclan.ac.uk

Tel: 01772894239

Fax: 01772892927

Author Biography:

Dr Leah Donlan is a Lecturer in Sports Marketing at the University of Central Lancashire, Preston, United Kingdom. She was awarded her PhD from Sheffield Hallam University in 2008 and her main research interests are in the use of sponsorship to build successful brands and the use of social media in sponsorship activation.

*Author responsible for correspondence and correction of proofs

CLoK ref 4946 


\section{The Role of Brand Knowledge in Determining Sponsorship Effectiveness}

\section{$\underline{\text { Abstract }}$}

Using the theoretical framework of consumer-based brand equity, this paper reports findings from a cross-sectional survey, measuring the comparative brand-building effectiveness of sponsorship for new and established brands. Results suggest that sponsorship is capable only of building awareness for new brands, while for an established brand, sponsorship exposure is found to impact positively on brand associations, perceived quality and brand loyalty. The need for an underlying level of brand knowledge for image transfer to occur is proposed, suggesting that the brand-building role of sponsorship is one of reinforcement, rather than creation. The findings have practical implications relating to sponsorship selection.

Keywords: sponsorship; effectiveness; brand associations; brand equity; brand knowledge 
Introduction

The past 20 years have seen considerable growth in the use of sponsorship, with Reuters (2011) reporting that global sponsorship expenditure totalled $\$ 46.6$ billion in 2010 , up from only \$2 billion in 1984 (Meenaghan, 1998). This exponential growth in expenditure, coupled with growing pressure to demonstrate return on marketing investment has led to an increased focus amongst both academics and practitioners on assessing the effectiveness of sponsorship as a marketing communications tool.

One area of sponsorship which has received considerable attention is that of objectives, with many studies exploring the evolution of objectives pursued by sponsors. Brand building objectives of awareness (Tomasini et al, 2004) and image (Hartland et al, 2005) are frequently cited although there is growing evidence that sponsorship is being used to achieve more sophisticated relationship-based goals through the creation of customer 'experiences' (Cliffe and Motion, 2005). The evolution of sponsorship objectives from an early notion of philanthropy through to the current emphasis on key brand metrics, positions sponsorship firmly as a commercially-driven marketing communications tool, as emphasised in this definition by IEG (2000, cited in Cornwell et al, 2005:21):

Sponsorship is: 'a cash and/or in-kind fee paid to a property (typically a sports, entertainment, non-profit event or organization) in return for access to the exploitable commercial potential associated with that property.'

The objectives pursued by sponsors are increasingly focussed on brand building and development and the value added by brands has been a recent growth area in research within 
marketing (Keller, 2009). Considerable previous research has looked at the range of necessary conditions for brand image transfer to occur in the context of sponsorship, focussing particularly on the role of clutter (Cornwell, 2000), involvement (Grohs and Reisinger, 2005; Bennett et al, 2009) and fit (Gwinner, 1997; Dees et al, 2010). While previous studies have explored the role played by sponsor prominence (Pham and Johar, 2001), the investigations have been limited to assessing the effect on awareness. However, there remain considerable gaps in our understanding of the wider role of sponsorship in building other elements of brand equity. As sponsorship expenditures and pressure to provide evidence of return on investment both increase, so there is a growing need to further understand the wider contribution that can be made by sponsorship to brand development goals.

There exists a considerable amount of literature documenting the impact of advertising on brand equity (Kim, 2001) and several studies have examined managerial perceptions relating to sponsorship, with findings suggesting that managers perceive sponsorship to impact positively on brand equity (Cornwell et al, 2001; Henseler et al, 2011). However, the true power of a brand (and thus the source of its equity) lies in what resides in the minds of consumers (Keller, 2001; Viosca et al, 2005). Thus, the need to substantiate findings from managerial studies empirically among consumers has been identified by Henseler et al (2011). Therefore, this study builds upon previous work, and in response to Cornwell's (2008) call to assess the effectiveness of sponsorship through the use of theoretical frameworks, applies Aaker's (1991) model of consumer-based brand equity to the case of sports sponsorship from a consumer-perspective. 
Much previous sponsorship research has looked at well-known, established brands such as Adidas (Chanavat et al, 2009), and has examined high profile event sponsorships such as the Olympic Games (Söderman and Dolles, 2008) and the FIFA World Cup (Nufer and Bühler, 2010), but there are numerous practical examples of sponsorship being used to launch brands, such as Lenovo (Clark, 2006). The role of brand familiarity has been examined in relation to sponsorship (Cornwell et al, 2005; Carrillat et al, 2010); however, studies have provided conflicting evidence relating to its impact on consumer response to sponsorship. Thus, the particular focus in this study is to explore the brand building effect of sports sponsorship for a new and an established brand. This study is different in that it assesses the effect of brand knowledge on not only brand awareness but also brand associations, perceived quality and brand loyalty. Equally, in a departure from many previous experimental investigations (e.g. Johar and Pham, 1999; Pham and Johar, 2001; Washburn and Plank, 2002), this study assesses sponsorship effectiveness in live sponsorship settings. As such, the differential effectiveness of sponsorship under conditions of high and low brand knowledge is explored, in order to further our understanding of the role played by brand knowledge structures in determining sponsorship success. Therefore, the findings presented here have both managerial and academic implications for our understanding of how to maximise the effectiveness of sponsorship investment for new and established brands.

\section{$\underline{\text { Literature Review and Theoretical Framework }}$}

Consumer-based brand equity has been differentially defined as the value added to a product by the addition of a brand name (Aaker and Biel, 1993) and the effect of knowing a brand name on the response of the consumer to the brand, measured as the extent to which consumers are willing to pay more for a certain brand (Kotler, 2003). Given the complex 
conceptualisation of brands within the minds of consumers, a multidimensional model of consumer-based brand equity was proposed by Aaker (1991:15), who suggested that:

'Brand equity is a set of brand assets and liabilities linked to a brand, its name and symbol, that add to or subtract from the value provided by a product or service to a firm and/or that firm's customer.'

Within this model, consumer-based brand equity comprises brand awareness, brand associations, perceived quality, brand loyalty and other proprietary brand assets. In an alternative conceptualisation, Keller (1993:2) views customer-based brand equity as:

'the differential effect of brand knowledge on consumer response to the marketing of the brand...Customer-based brand equity occurs when the consumer is familiar with the brand and holds some favorable, strong, and unique brand associations in memory.'

Brand knowledge is posited to comprise both brand awareness and brand image. The elements of consumer-based brand equity therefore map closely with the commonly pursued sponsorship objectives, making it an appropriate theoretical framework within which to assess the effectiveness of sponsorship. Several previous studies have also examined various aspects of sponsorship, including brand image transfer and brand personality (Deane et al, 2003), managerial perceptions of sponsorship effectiveness (Cornwell et al, 2001), and the impact of sponsor fit (Henseler et al, 2007) using the theoretical framework of consumerbased brand equity, thus reinforcing its validity as a conceptual framework within this context. 
Based on the associative network memory model, the conceptualisation of brand equity implies a hierarchy with brand awareness preceding the creation of brand image (Keller, 1993). Awareness establishes a brand node in memory, to which a range of associations can subsequently be connected. One way of establishing these associations is through brand communications, which can impact on brand equity by influencing consumers' memory structures in relation to brands (Anantachart, 2005). Many types of information can become linked in memory to a brand, including images, thoughts, feelings and attitudes. Strong levels of awareness or familiarity with a brand may be necessary for certain of these associations to develop (Keller, 2003). Therefore, if sponsorship is to be effective at building brand associations, it is reasonable to assume that the consumer must possess a degree of awareness of the brand (Cornwell and Maignan, 1998).

Considerable empirical support exists for the ability of sponsorship to build brand awareness (Rines, 2002; Davies et al, 2006; Mason and Cochetel, 2006). However, Koschler and Merz (1995) claim that sponsorship is poor at building awareness and is rather used to push existing brand awareness; thus suggesting that, in isolation, sponsorship is not a suitable strategy for new brands. The need to combine marketing communications media is further reinforced by McCarthy and Fram (2008) who found that brand salience for a new brand was significantly higher when subjects were exposed to advertising and promotional products rather than one in isolation. While a detailed examination of the importance of sponsorship leverage (Papadimitriou and Apostolopoulou, 2009) is beyond the scope of this paper, such arguments also reinforce the need to support sponsorship with an integrated marketing communications programme to maximise effectiveness, particularly for new brands (Micu 
and Thorson, 2008). Building upon these previous studies and in line with the associative network memory model, the following hypothesis is proposed:

$\mathbf{H}_{1}$ : Exposure to sports sponsorship will have a greater positive impact on brand awareness for established brands than for new brands.

As a sponsorship objective, brand awareness is considered by sponsors to be particularly important (Lough and Irwin, 2001; Hartland et al, 2005); however, the effectiveness of sponsorship is enhanced if brands can go beyond mere awareness, and image transfer can occur (Roy and Cornwell, 2004). The nature of sponsorship as a communications vehicle makes the communication of product class associations problematic; however its strength lies in its ability to leverage secondary image associations from the sponsored property (Cornwell and Maignan, 1998).

Gwinner (1997) developed a model of image transfer in event sponsorship, building on McCracken's (1989) work on meaning transfer in celebrity endorsement. The model of image transfer in sponsorship has since been augmented by Smith (2004) who proposes that the degree of image transfer is impacted by both external (sponsorship composition, domain, status and duration) and internal (brand knowledge (recall and recognition) and brand image) factors. Therefore, brand knowledge is posited as a necessary prerequisite for sponsoring brands wishing to build non-awareness based elements of brand equity. The advantage of brand familiarity has been demonstrated in the context of advertising by Campbell et al (2003), who found that that familiarity with a brand had a positive impact on advertising repetition effectiveness. 
An alternative perspective is explored by Carrillat et al (2005), who claim that the formation of new brand associations through sponsorship will be greater for less familiar brands, as the absence of large volumes of existing associations will result in greater processing of sponsorship-related stimuli. The authors found empirical support for this argument, with positive brand attitude change occurring for low familiarity brands, while no effect was found for high familiarity brands. However, this study adopted an experimental methodology, using existing brands and events manipulated to represent high and low familiarity conditions. Therefore, whether such effects would persist in real-life sponsorship settings remains to be explored.

Studies looking at the impact of sponsor prominence on consumer response to sponsorships have found that lesser-known sponsors may not benefit as much as well-known sponsors in terms of awareness and image-building benefits (Johar and Pham, 1999; Pham and Johar, 2001). Johar and Pham (1999), in experimental studies of sponsor identification, found that the market prominence of sponsoring brands may be used as a heuristic by consumers in identifying sponsors. Equally, the prominence bias is more pronounced in cluttered sponsorship environments where it is harder for consumers to recall sponsor-event associations (Pham and Johar, 2001). While these experimental studies considered primarily the impact on sponsor identification (recall/recognition), prominent brands identified either correctly or incorrectly as sponsors, also benefitted in terms of enhanced brand image (Pham and Johar, 2001). It is also acknowledged that brands with a larger number of diverse associations are more accessible in memory, thus increasing their likelihood of appearing in consumer consideration sets (Hoeffler and Keller, 2003). 
The fit between sponsor and event is often postulated to impact upon the effectiveness of sponsorship (Simmons and Becker-Olsen, 2006; Weeks et al, 2008), with brands demonstrating some relatedness to the event more likely to be identified as sponsors (Johar and Pham, 1999) and generating a more favourable response from sponsorship (Speed and Thompson, 2000). Equally, sponsorship fit was identified by Martensen et al (2007) as crucial for the transfer of values between events and sponsors. However, the current study, in exploring sponsorship effectiveness for new and established brands, does not examine the role of sponsor-event fit. Nonetheless, to further our understanding of how sponsorship works, further research in the area of sponsor-event fit is advocated.

While the development of a comprehensive model of how sponsorship works remains elusive, considerable academic interest has focussed on how advertising works as a communications tool. Ehrenberg (1974) criticises the strong theory of advertising (Lavidge and Steiner, 1961) arguing that the role of advertising is primarily to reinforce what consumers know about a brand. In comparing sponsorship and advertising, Hastings (1984) claims that the differences between the two are more a matter of degree than kind. Hoek et al (1999) found higher levels of recall of brands as sponsors by customers than non-customers; therefore it is possible that sponsorship may also have a reinforcement role. Equally, Hoek et al (1997) identified that while there were differences in the specific effects, particularly concerning awareness and associations, both sponsorship and advertising stimuli evoked consumer responses in line with the ATR model. However, more recent research by Chanavat et al (2009) suggests that sponsorship works in line with the hierarchy of effects model.

Numerous studies have explored the relationship between sponsorship and brand image change (Gwinner and Eaton, 1999; Nufer and Bühler, 2010), including building a perception 
of quality (Pope et al, 2009). The ability of sponsorship to go beyond awareness to impact on the higher order elements of brand equity is tested empirically in this study, exploring the contribution of sports sponsorship to elements of consumer-based brand equity for a new (low brand knowledge) and an established (high brand knowledge) brand. Consequently, the following hypotheses are proposed:

$\mathbf{H}_{2}$ : Exposure to sports sponsorship will have a greater positive impact on brand associations for established brands than for new brands.

$\mathbf{H}_{3}$ : Exposure to sports sponsorship will have a greater positive impact on perceived quality for established brands than for new brands.

Brand owners increasingly understand the value of customer loyalty and retention (Too et al, 2001; Helgesen, 2006), and as the only element of brand equity with a direct link to behaviour, brand loyalty can be a major driver of sales and profits. However, the relationship between brand loyalty and sponsorship has received little attention, possibly as a result of the difficulty in ascribing purchasing behaviours to a single marketing communications tool. Nonetheless, some support has been found for sponsorship's ability to build brand loyalty (Levin et al, 2004). Therefore, the following hypothesis is proposed:

$\mathbf{H}_{\mathbf{4}}$ : Exposure to sports sponsorship will have a greater positive impact on brand loyalty for established brands than for new brands.

\section{Methodology}

This study uses a modified version of the Aaker (1996) brand equity measurement tool to assess brand equity scores for two sponsors, one new and one established brand. The study adopted a cross-sectional survey methodology to overcome a prominent shortcoming of much 
previous experimental sponsorship research: the lack of generalizability to live market settings. The collection of data in live sponsorship environments is therefore an important contribution of this study as it assesses the effectiveness of sponsorship under the prevailing market conditions, rather than the controlled and isolated experimental conditions frequently used in previous research. This study therefore more accurately represents the conditions under which consumers receive sponsorship messages, with the associated clutter and other elements fighting for consumer attention. With a growing need among practitioners for evidence of sponsorship effectiveness, conducting research under live market conditions increases the ecological validity (Gill and Johnson, 2002) of the study, by more accurately representing the reality of consumer decision making and sponsorship exposure.

\section{Instrument Development}

Data were collected via self-administered questionnaires at two sponsored sporting events and via self-administered postal questionnaires among two comparison samples not directly exposed to the sponsorship activities. Evident as a limitation of self-administered questionnaires is the potential for social desirability bias, with respondents wishing to present themselves in the best light (Fisher, 1993). This could have resulted in, for example, respondents scoring brands more favourably or overstating sponsor recognition. Consequently, the use of self-administered questionnaires could potentially have led to skewed results by masking true relationships and/or producing spurious relationships (Ganster et al, 1983; Phillips, 2009). However, the use of self-administered questionnaires was deemed necessary to facilitate researchers obtaining a larger sample within the time constraints of the events. Equally, respondents were informed that the researcher had no connection with the brands and that it was a piece of academic research, in an attempt to 
minimise any potential for social desirability bias (in the sense of respondents responding with what they thought the researcher would want to hear). The questionnaire was piloted in a live sports sponsorship setting in the United Kingdom $(n=50)$. As a result of the pilot study, several questionnaire items were modified in order to speed up completion time, thus maximising the number of responses achievable. The final selection of measures of consumer-based brand equity was based upon the judgement of the researcher, balancing the need to fully cover all elements while attempting to reduce the time and effort burden of completion for respondents.

In line with Aaker's (1996) measurement tool, the final list of measures under the headings of brand awareness, brand associations, perceived quality and brand loyalty is shown below in Table 1. Although presenting a comprehensive suite of brand equity measures, Aaker (1996) acknowledges that not all measures will be suitable for all brands, therefore the tool was modified accordingly. The measures used were selected on the basis of suitability/relevance for the brands under investigation and ability to effectively capture the key dimensions of consumer-based brand equity. The calculation of a price premium (an indicator of brand loyalty) was omitted as it was considered too onerous for respondents to complete in the data collection setting. Similarly, the brand associations element of 'rich history' was removed as this was not deemed appropriate when investigating a new brand. Other measures such as 'admiration' (brand associations) and 'esteem' (perceived quality) were removed in order to reduce the length of the questionnaire, as they were deemed close substitutes of other measures such as 'trust' (brand associations) and 'respect' (perceived quality), while 'the brand is the only one/one of several I buy' (brand loyalty) was removed as this is less relevant in the financial services sector where purchase frequency is lower than, for example, FMCG markets. 
[Place Table 1 about here]

The individual elements of brand associations, perceived quality and brand loyalty were measured on a five point scale from 'totally agree' to 'totally disagree'. In line with Aaker's (1991) conceptualisation of brand equity as being either an asset or a liability, the two values indicating degrees of disagreement represented a negative opinion of the brand, while positive attitudes were captured by values at the opposite end of the scale. In the context of this study where respondents may have had little experience of the brands in question, it was considered pertinent to offer a 'don't know/not applicable' option rather than to force respondents into an unrepresentative response. If many respondents select a 'don't know' option, this is not to be viewed as a problem but rather as an interesting finding (Aldridge and Levine, 2001), in this case indicative of a lack of brand knowledge.

A decision was made regarding the ordering of 'neither agree nor disagree' and 'don't know/not applicable' according to the relative level of brand knowledge associated with each value. Therefore, the distinction is made between presence/absence of a brand attitude ('don't know' response) and the strength of any attitude held (neutral 'neither agree nor disagree' attitude implying some degree of brand knowledge). Consequently, the variables for each element of brand equity were scored from -2 (totally disagree) to +3 (totally agree), with 'neither agree nor disagree' scored as 1 and 'don't know/not applicable' scored as 0. The scores for each of the six components were summed to produce overall scores (ranging from -12 to +18 ) for brand associations, perceived quality and brand loyalty for each brand respectively. Brand equity scores for each brand are analysed separately as each brand 
represents a different baseline level of brand awareness, therefore, combining them would conflate the existing differences between the new and established brands.

Internal reliability of measures of brand associations, perceived quality and brand loyalty was measured using Cronbach's alpha. In the case of each sponsor brand under investigation, scores for the groupings of brand associations, perceived quality and brand loyalty exceeded the recognised cut-off value of 0.7 (Henerson et al, 1987).

\section{Data Collection}

Data were collected at two sponsored elite sports events in the UK, one sponsored by a newly launched brand (event sample $n=114$, comparison sample $n=280$ ) and one sponsored by an established brand (combined event sample $\mathrm{n}=206$, comparison sample $\mathrm{n}=141$ ).

Comparison sample groups represented a series of convenience samples of individuals not present at either event, from the membership list of an organisation known to the author. The group had no connection with any of the sporting events and contained a broad mix of ages and genders (demographic data for event-based and comparison samples is displayed below in Table 2). Separate comparison samples were used for each sponsor brand to avoid respondent fatigue. While it is acknowledged that assessing the generalizability of the convenience sample to the wider population is not possible (Bryman and Bell, 2003), such a sampling approach was necessary in order to gather the required data in the short time frame around the events in order to minimise the impact of other marketing communications from the sponsoring brands. Differing sample sizes between event-based and comparison samples are a function of differing response rates among comparison sample groups and data collection time constraints at the sporting events. Both sponsor brands operate within the 
financial services industry and are customer-facing, therefore facilitating comparison between the two and reinforcing the suitability of consumer-based brand equity as a measure of brand value. Conducting research in live sponsorship settings inevitably sacrifices control over extraneous variables such as exposure to other marketing communications (Gill and Johnson, 2002); however by administering the questionnaires to event-based and comparison samples within the same time period, the researchers attempted to overcome such influences.

Respondents at the events were asked to complete the questionnaires prior to or during breaks in play. The absence of a pre-existing sampling frame resulted in the event-based researchers using convenience sampling in order to maximise the number of responses. The demographic profiles of respondents seemed to match the demographic profiles of event attendees, therefore it is reasonable to assume that the two samples are broadly representative of the populations attending the events under investigation.

\section{$\underline{\text { Results }}$}

\section{Demographic Data}

Table 2 outlines the demographic profile of respondents at the events and in the comparison groups, including, where marked, significant differences between sample groups on such variables. In comparing event-based and comparison sample groups it is not possible to know if the groups differ on any meaningful variables other than sponsorship exposure (Black, 1999). However, such a trade off (as a result of no pre-existing sampling frames) is necessary if data is to be gathered in live sponsorship environments to more accurately reflect prevailing sponsorship market conditions. 
[Place Table 2 about here]

\section{New Brand Sponsor}

Among event-based respondents, top-of-mind sponsorship awareness (i.e. first named sponsor) was $16.5 \%$, with aided sponsor recognition of $41.7 \%$. Therefore, the link between the sponsor and the event is moderately strong, although over half of respondents present at the event were unable to recognise the brand as a sponsor.

For the new brand sponsor, brand awareness among the event-based sample $(51.3 \%)$ was significantly higher than among the comparison sample $(5.0 \%)\left(\chi^{2}(1)=116.016, p=0.000\right)$. Therefore, for a new brand, sponsorship exposure appears to be impacting considerably upon brand awareness, which, as discussed above, is a prerequisite for the development of further brand associations. As only $5 \%$ of the comparison sample had heard of the brand, the sample size for subsequent questions is severely limited $(n=14)$. Therefore, caution must be exercised when interpreting these results.

Perhaps the most basic association to a brand will be the product category in which the brand operates. For the new brand sponsor, $76.9 \%$ of event-based respondents aware of the brand cited a product association of financial services. Among those aware of the brand in the comparison sample, this figure was $38.5 \%$. Therefore, for a new brand there is evidence that sports sponsorship can communicate some product category associations. Interestingly, among those aware of the brand in the comparison sample, the first association with the brand was cited as sports sponsorship by $46.2 \%$ of respondents. Therefore, it appears that for 
sponsorship to communicate product associations, a deeper level of involvement (i.e. direct exposure at the event) is required.

As shown in Table 3, there was no significant difference in mean scores for brand associations $(\mathrm{t}=0.124, \mathrm{p}=0.899)$, perceived quality $(\mathrm{t}=0.747, \mathrm{p}=0.465)$ or brand loyalty $(\mathrm{t}$ $=1.000, \mathrm{p}=0.338$ ) between those exposed and those not exposed to the sponsorship activity. Therefore, in the case of the new brand sponsor, no positive impact is found on brand associations, perceived quality or brand loyalty as a result of exposure to sports sponsorship. Among both event-based and comparison sample respondents, responses clustered in the 'don't know/not applicable' category, indicating a lack of brand knowledge among both those exposed and those not exposed to the sponsorship. Table 4 shows the mean scores for the new brand sponsor on each individual element of brand associations, perceived quality and brand loyalty for the event-based and the comparison samples. The only dimension on which those exposed to sponsorship scored significantly higher than those not exposed was comparison with competitors $(\mathrm{t}=2.647, \mathrm{p}=0.016)$. However, both mean scores are below 1 (neither agree nor disagree), showing that while the difference is statistically significant, in terms of contribution to perceived quality, the effect is negligible.

[Place Table 3 about here]

[Place Table 4 about here]

In order to fully explore the impact of brand knowledge on consumer response to sponsorship, comparison was made between the brand equity scores among those in the comparison sample who were aware of some sponsorship activity by the brand and those who 
had heard of the brand but were not aware of any sponsorship activities. $78.6 \%$ of those respondents in the comparison sample who were aware of the brand were aware of some sponsorship activity by the brand. The mean scores for brand associations $(\mathrm{t}=0.195, \mathrm{p}=$ $0.862)$, perceived quality $(\mathrm{t}=0.386, \mathrm{p}=0.735)$ and brand loyalty $(\mathrm{t}=0.526, \mathrm{p}=0.688)$ were higher for those aware of sponsorship activity, but these differences were not found to be significant. Therefore, as with those directly exposed to sponsorship at the event, there is no evidence for sponsorship's ability to go beyond mere awareness for a new brand.

\section{Established Brand Sponsor}

For the established brand sponsor, among event-based respondents, top-of-mind sponsor recall was $78.2 \%$, with aided sponsor recognition of $92.2 \%$. Therefore, there exists a strong link between the sponsor and the event. Extending from sponsorship awareness, brand awareness for the established brand sponsor was $98.5 \%$ among the event-based sample and $97.9 \%$ in the comparison sample. This sponsor represents a very well-known brand within the financial services industry and as such the level of brand knowledge for the established brand sponsor is much greater than that for the new brand sponsor. Unsurprisingly, given the high levels of brand awareness, no significant difference was found between the scores of those exposed and those not exposed to sponsorship $\left(\chi^{2}(1)=0.222, p=0.637\right)$. When considering this along with the results obtained for the new brand sponsor, no support was found for hypothesis $\mathrm{H}_{1}$, as the greater impact on brand awareness was found for the new brand. 
For the established brand sponsor, $94.2 \%$ of those exposed to the sponsorship correctly identified the brand with financial services. Within the comparison sample, this figure was 93.6\%. Therefore, the brand possesses strong product category associations.

As shown in Table 5, those exposed to sponsorship at the event scored significantly higher on brand associations $(\mathrm{t}=4.061, \mathrm{p}=0.000)$, perceived quality $(\mathrm{t}=2.426, \mathrm{p}=0.016)$ and brand loyalty $(\mathrm{t}=2.972, \mathrm{p}=0.003)$ than those in the comparison sample. Therefore, the results suggest that sports sponsorship had a positive impact on brand associations, perceived quality and brand loyalty for the established brand but not for the new brand; thus support is found for hypotheses $\mathrm{H}_{2}, \mathrm{H}_{3}$ and $\mathrm{H}_{4}$.

[Place Table 5 about here]

Table 6 shows the mean scores for the event-based and comparison samples on the individual elements of brand associations, perceived quality and brand loyalty. In terms of brand associations, those exposed to sponsorship scored significantly higher on reason to purchase $(\mathrm{t}=2.874, \mathrm{p}=0.004)$, differentiation $(\mathrm{t}=2.190, \mathrm{p}=0.029)$, distinctive personality $(\mathrm{t}=3.319$, $\mathrm{p}=0.001)$, value for money $(\mathrm{t}=2.201, \mathrm{p}=0.028)$ and user image $(\mathrm{t}=4.310, \mathrm{p}=0.000)$. Significantly higher scores were found among those exposed to the sponsorship on the perceived quality dimensions of leadership $(\mathrm{t}=2.942, \mathrm{p}=0.004)$, growing in popularity $(\mathrm{t}=$ $3.171, \mathrm{p}=0.002)$ and innovation $(\mathrm{t}=2.309, \mathrm{p}=0.022)$, and the brand loyalty elements of expressed loyalty $(t=3.740, p=0.000)$ and purchase intention $(t=3.094, p=0.002)$. A significant difference was also found on the dimension of willingness to pay a higher price $(\mathrm{t}$ $=3.746, \mathrm{p}=0.000)$, but the mean scores of both sample groups were negative, indicating a 
general lack of willingness to pay a price premium. Therefore, while this difference is statistically significant, it is not meaningful in terms of building brand loyalty.

[Place Table 6 about here]

Within the comparison sample, $8.4 \%$ respondents who were aware of the brand were aware of some sponsorship activity by the established brand sponsor. The mean scores on brand associations $(t=1.270, p=0.207)$, perceived quality $(t=1.060, p=0.292)$ and brand loyalty $(t=0.316, p=0.753)$ were higher for those aware of sponsorship activity, but these differences were not found to be statistically significant. Therefore, while exposure to sponsorship stimuli at an event can contribute to higher levels of consumer-based brand equity, there is no evidence that mere knowledge of sponsorship activity has a similar effect for an established brand.

\section{$\underline{\text { Discussion }}$}

\section{Brand Awareness}

The above results suggest that sponsorship can be a driver of brand awareness for new brands. Building brand awareness is particularly important for new brands (Farr, 1999; Franzen and Bouwman, 2001) as it is a prerequisite for developing further brand associations (Keller, 2003). There was no significant impact on brand awareness for the established brand, however, in line with Koschler and Merz's (1995) contention, the high level of brand awareness for the established brand sponsor among the event-based sample suggests that for 
established brands, sponsorship may serve a reinforcement role. Therefore, in this case no support was found for hypothesis $\mathrm{H}_{1}$.

\section{The Role of Prior Brand Knowledge}

In addition to building brand awareness, there is evidence that sponsorship contributed to the development of product category associations for the new brand. These findings therefore contradict the views of Ukman (2004), who claimed that sponsorship is poor at communicating product class associations. However, while there was a general increase in association with the broad product category of financial services, the only specific product to be mentioned by respondents at the event was insurance, which is just one of many products offered by the new brand. Therefore, the brand knowledge being created is at a very general level and as such there is a lack of detailed brand familiarity. As Keller (2001) suggests, unless identification of the brand with a specific product class or consumer need has been established, brand meaning (i.e. higher order elements of brand equity) cannot be developed.

The development of product category associations, however, was limited to those directly exposed to the new brand's sponsorship at the event. Among the comparison sample aware of the brand, the most cited association was sports sponsorship. This, therefore, has implications for the use of sponsorship as a vehicle for reaching target markets through the medium of television; these results suggest that mediated consumers achieve only brand name visibility. As the comparison sample for this brand was so small, an investigation into the comparative effectiveness of sponsorship among live and mediated consumers should become a future research priority. 
Beyond general product category associations, sponsorship appeared to have no discernible impact on consumer-based brand equity for the new brand. Aaker (2002) uses the analogy of brands as mental billboards, with the relative size of the billboard representing the level of brand knowledge. Similarly, using the associative network memory model, Keller (1993) posits that brands form a node within memory, to which additional pieces of information can be added. Unlike the established brand, as a new brand, consumers do not have a base level of brand knowledge of the new brand sponsor; therefore the brand node may not be strong enough for subsequent abstract linkages to attach to. The established brand sponsor had an existing stock of brand knowledge among consumers due to its time in market and also the significant additional promotional activities undertaken in addition to sponsorship.

At the time of this research, sponsorship was the primary communications vehicle used by the new brand sponsor, and at the event in question, there was little evidence of leverage activities beyond on-site signage. Skildum-Reid (2003) questions the marketing return of sponsorship when sponsors simply place a logo in front of consumers. Ehrenberg (1974) suggests that advertising is used primarily to reinforce what consumers already know about a brand and the evidence presented in this paper suggests that sponsorship may have a similar function. For the established brand, sponsorship had a discernible impact upon consumerbased brand equity, building upon and augmenting the existing brand associations held in memory. As a new brand and with an absence of supporting communications materials, the new brand sponsor did not appear to have this stock of existing brand knowledge upon which to build; as such support was found for hypothesis $\mathrm{H}_{2}$. As with most communications activities, sponsorship is just one of a range of sources of information used by consumers in brand image formation (Fenton, 2005). Therefore, these results suggest the role of sponsorship may be weak in terms of forging new brand associations under conditions of low 
brand knowledge where the brand node is itself not sufficiently developed to facilitate the addition of image-based associations.

In the case of established brands using sponsorship within an integrated marketing communications programme, there is evidence that sponsorship can aid the development of such associations as a strong brand node exists in consumers' memories. As such, the established brand, with its existing stock of brand equity is able to benefit from greater marketing communications effectiveness (Keller and Hoeffler, 2003; Viosca et al, 2005) in terms of the impact of its sponsorship on brand associations. This contention has considerable implications for the selection of appropriate sponsorship opportunities. However, the evidence presented here is limited to two brands; therefore a proposed area for future research is to further explore the relationship between existing brand knowledge and consumer response to sponsorship, to test the strength of impact sponsorship can have, particularly for new brands.

The findings for brand associations were replicated for the other dimensions of brand equity: perceived quality and brand loyalty. Thus, support was found for hypotheses $\mathrm{H}_{3}$ and $\mathrm{H}_{4}$. Again, the evidence presented here implies that in order to build higher-order elements of consumer-based brand equity, brands need to have strong existing node structures in consumer memory to facilitate additional sponsorship-related linkages.

\section{$\underline{\text { Limitations and Future Research }}$}

Unlike many investigations into sponsorship effectiveness, this study adopted a crosssectional survey methodology in real-life sports sponsorship settings. Therefore, a trade-off 
was made between strict control of extraneous variables and the ability to capture sponsorship effectiveness in a real market context. As such, it is difficult to entirely isolate the impact of sponsorship. However, as the findings of this study illustrate, sponsorship does not and should not exist in isolation; therefore true measures of its effectiveness need to take into account the prevailing competitive arena in which sponsors operate. This study took a snapshot view of brand equity at one moment in time; therefore an interesting avenue for future research, to address this limitation, would be to conduct a longitudinal study, particularly focussed on assessing the evolving contribution of sponsorship over the life of newly launched brands. Equally, a longitudinal study exploring the carry over effects of sponsorship for both new and established brands would further enhance our understanding of the long-term brand-building role of sponsorship.

Conducting research in live event settings meant that no pre-existing sampling frame existed and as such convenience samples were used at both sponsored events. This decision was made in order to maximise responses in a time- and resource-constrained data collection environment. Therefore, it is not possible to generalise these findings beyond the specific contexts discussed here. As such, this study should be replicated across a range of sponsorship settings and sponsor product categories to examine whether the results persist. Equally, the differences in demographic profiles between event-based and comparison samples, particularly for the new brand sponsor, represent a limitation of this study. While it is acknowledged that demographic variables are likely to impact on prior brand exposure, for the new brand sponsor, brand awareness was low amongst both sample groups, indicating a generalised lack of prior exposure to the brand. However, an area for future research is to replicate the study for a new brand with matched samples to explore if demographic factors impact upon the results obtained. 
The comparison between a new and established brand led to a situation whereby the level of awareness of the new brand among the comparison sample was particularly low. Therefore, the sample size was severely limited, thus compromising some of the data analysis and possibly influencing the lack of significant differences in brand equity scores for the new brand (Black, 1999). The size of samples is thus acknowledged as a limitation of this study, largely driven by the time-constrained data collection environments at sporting events, combined with the low brand familiarity condition for one sponsor brand. Several previous studies have adopted an experimental methodology in order to create conditions of low brand familiarity (Phelps and Thorson, 1991), which overcomes the problem of small sample sizes. As discussed above, there is a trade-off between experimental and survey-based methodologies in terms of ecological validity and it is thus recommended that a similar study be conducted under experimental conditions to explore whether the results persist with larger sample sizes.

A final area for future research is in exploring the nature of how sponsorship works. Hoek et al (1997) contrasted the effects of sponsorship and advertising; therefore with the above contention that sponsorship appears to be more powerful at reinforcing brand associations for existing brands than at forging associations for new brands, further investigation is warranted into the applicability of advertising models, such as ATR, to the context of sponsorship. Within the topic of how sponsorship works, as discussed above, many variables such as sponsor-event fit, involvement and clutter have been proposed as playing a moderating role in sponsorship recall/recognition and image transfer. Similarly, this paper has explored the role of sponsorship for new and established brands, but in line with the work of Johar and Pham (1999), further inquiry into the impact of market share or prominence on sponsorship's brand 
building role is recommended. While out of the scope of this paper, an extension of this study to model the effects of such variables would contribute to the development of a more comprehensive model of how sponsorship works.

\section{$\underline{\text { Conclusion }}$}

Supporting the views of Johar and Pham (1999) and Pham and Johar (2001), this study found that, in terms of building consumer-based brand equity, lesser known brands benefit significantly less than established brands from engaging in sports sponsorship. While sponsorship exposure was found to contribute to greater brand awareness for a new brand, this effect did not carry over to higher order elements of consumer-based brand equity. However, for an established brand, sponsorship was found to contribute to higher scores on brand associations, perceived quality and brand loyalty. Carrillat et al (2005) posited that the transfer of associations to sponsors would be greater for new brands, suggesting that consumers would engage in greater processing of information in the absence of large amounts of existing brand knowledge. However, the findings of this study suggest that an existing level of brand knowledge is required before the transfer of intangible associations from sponsored property to sponsor can take place.

Roy and Cornwell (2004) suggest that high existing brand equity and market prominence can make it easier for consumers to perceive a link between sponsor and event, which is a prerequisite for image transfer. The positive impact of sponsorship on the established brand in this study suggests that it is the existing level of brand equity which influences the brandbuilding power of sponsorship. As such, the role of sponsorship appears to be more one of reinforcement than of creating new brand associations. The findings from this study present 
clear implications for sponsors in terms of correctly selecting and activating sponsorships according to existing levels of brand knowledge. In assessing the differential effectiveness of sponsorship under conditions of high and low brand knowledge and in real-life sponsorship settings, this study has built upon our existing understanding of how sponsorship works, proposing a reinforcement function as the primary role of sponsorship. Further research to test this proposition across a wider range of sponsorship settings is therefore recommended in order to continue to develop our understanding of how sponsorship works.

\section{$\underline{\text { References }}$}

Aaker, D. A. (2002). Building Strong Brands. London, Simon \& Schuster.

Aaker, D. A. (1996). Measuring brand equity across products and markets. California Management Review, 38 (3), 102-120.

Aaker, D. A. (1991) Managing Brand Equity. Capitalizing on the value of a brand name. New York, Free Press.

Aaker, D. A. and Biel, A. L. (1993). Brand equity and advertising: An overview. In: Aaker, D. A. and Biel, A. L. (eds.). Brand equity and advertising. Hillsdale, NJ, Lawrence Erlbaum Associates, 1-8.

Aldridge, A. and Levine, K. (2001). Surveying the social world Principles and practice in survey research. Buckingham, Open University Press.

Anantachart, S. (2005). Integrated Marketing Communications and Market Planning: Their Implications to Brand Equity Building, Journal of Promotion Management 11 (1), 101 125.

Bennett, G., Ferreira, M., Lee, J. and Polite, F. (2009). The role of involvement in sports and sport spectatorship in sponsor's brand use: The case of Mountain Dew and Action Sports sponsorship, Sport Marketing Quarterly 18 (1), 14-24.

Black, T. R. (1999). Doing quantitative research in the social sciences. London, Sage.

Bryman, A. and Bell, E. (2003). Business Research Methods. Oxford, Oxford University Press.

Campbell, M.C., Keller, K.L., Mick, D.G. and Hoyer, W.D. (2003). Brand familiarity and advertising repetition effects, Journal of Consumer Research 30 (2), 292-304. 
Carrillat, F.A., Harris, E.G. and Lafferty, B.A. (2010). Fortuitous brand image transfer: investigating the side effect of concurrent sponsorships, Journal of Advertising 39 (2), 109123.

Carrillat, F.A, Lafferty, B.A and Harris, E.G (2005) Investigating sponsorship effectiveness: Do less familiar brands have an advantage over more familiar brands in single and multiple sponsorship arrangements? Journal of Brand Management 13 (1), pp. 50-64.

Chanavat, N., Martinent, G. and Ferrand, A. (2009). Sponsor and sponsees interactions: effects on consumers' perceptions of brand image, brand attachment, and purchasing intention, Journal of Sport Management 23 (5), 644-670.

Clark, N. (2006) Lenovo forges 2008 Olympics link with Coca-Cola, Marketing 8/2/06, 3.

Cliffe, S. J. and Motion, B. (2005). Building contemporary brands: A sponsorship-based strategy. Journal of Business Research, 58 (8), 1068-1077.

Cornwell, T.B (2008) State of the art and science in sponsorship-linked marketing. Journal of Advertising, 37 (3), 41-55.

Cornwell, T. B. (2000). Understanding long-term effects of sports sponsorship: Role of experience, involvement, enthusiasm and clutter. International Journal of Sports Marketing \& Sponsorship, 2 (2), 127-142.

Cornwell, T. B. and Maignan, I. (1998). An international review of sponsorship research. Journal of Advertising, 27 (1), 1-21.

Cornwell, T. B., Roy, D. P. and Steinard, E. A. (2001). Exploring managers' perceptions of the impact of sponsorship on brand equity. Journal of Advertising, 30 (2), 41-51.

Cornwell, T.B., Weeks, C.S. and Roy, D. P. (2005). Sponsorship-linked marketing: opening the black box, Journal of Advertising 34 (2), 21-42.

Davies, F., Veloutsou, C. and Costa, A. (2006). Investigating the influence of a joint sponsorship of rival teams on supporter attitudes and brand preferences, Journal of Marketing Communications 12 (1), 31-48.

Deane, J., Smith, G. and Adams, A. (2003). Sports sponsorship and brand personality - the Ryder Cup Team and IBM. International Journal of Sports Marketing \& Sponsorship, 5 (3), 193-208.

Dees, W., Bennett, G. and Ferreira, M. (2010). Personality fit in NASCAR: an evaluation of driver-sponsor congruence and its impact on sponsorship effectiveness outcomes, Sport Marketing Quarterly 19 (1), 25-35.

Ehrenberg, A. S. C. (1974). Repetitive advertising and the consumer. Journal of Advertising Research, 14 (2), 25-34. 
Farr, A. (1999). How advertising builds brand equity. In: Jones, J. P. (ed.). How to use advertising to build strong brands. Thousand Oaks, CA, Sage, 177-193.

Fenton, W. (2005). Sports sponsorship in first place. Brand strategy, 191, 37-39.

Fisher, R. J. (1993). Social desirability bias and the validity of indirect questioning, Journal of Consumer Research 20 (2), 303-315.

Franzen, G. and Bouwman, M. (2001). The mental world of brands. Henley-on-Thames, World Advertising Research Center.

Ganster, D.C., Hennessey, H.W. and Luthans, F. (1983). Social desirability response effects: three alternative models, Academy of Management Journal 26 (2), 321-331.

Gill, J. and Johnson, P. (2002). Research methods for managers. 3rd ed., London, Sage.

Grohs, R. and Reisinger, H. (2005). Image transfer in sports sponsorships: an assessment of moderating effects, International Journal of Sports Marketing \& Sponsorship 7 (1), 42-48.

Gwinner, K. (1997). A model of image creation and image transfer in event sponsorship. International Marketing Review, 14 (3), 145-158.

Gwinner, K. P., and Eaton, J. (1999). Building brand image through event sponsorship: the role of image transfer, Journal of Advertising 28 (4), 47-57.

Hartland, T., Skinner, H. and Griffiths, A. (2005) "Tries and conversions: are sports sponsors pursuing the right objectives?" International Journal of Sports Marketing \& Sponsorship 6 (3), 164-173.

Hastings, G.B. (1984) Sponsorship works differently from advertising. International Journal of Advertising, 3 (2), 171-176.

Helgesen, Ø. (2006) Are loyal customers profitable? Customer satisfaction, customer (action) loyalty and customer profitability at the individual level. Journal of Marketing Management, $22(3 / 4), 245-266$.

Henerson, M. E., Morris, L. L. and Fitz-Gibon, C. T. (1987). How to measure attitudes. Newbury Park, CA, Sage.

Henseler, J., Wilson, B., Götz, O. and Hautvast, C. (2007). Investigating the moderating role of fit on sports sponsorship and brand equity. International Journal of Sports Marketing \& Sponsorship 8 (4), 321-329.

Henseler, J., Wilson, B. and Westberg, K. (2011). Managers' perceptions of the impact of sport sponsorship on brand equity: which aspects of the sponsorship matter most? Sport Marketing Quarterly 20 (1), 7-21.

Hoeffler, S and Keller, K.L (2003) The marketing advantages of strong brands, Journal of Brand Management 10 (6), pp. 421-445. 
Hoek, J., Gendall, P., Jeffcoat, M. and Orsman, D. (1997). Sponsorship and advertising: A comparison of their effects. Journal of Marketing Communications, 3 (1), 21-32.

Hoek, J., Gendall, P. and Theed, K. (1999). Sports sponsorship evaluation: A behavioural analysis. International Journal of Sports Marketing \& Sponsorship, 1 (4), 328-343.

Johar, G. V. and Pham, M. T. (1999). Relatedness, prominence, and constructive sponsor identification. Journal of Marketing Research, 36 (3), 299-312.

Keller, K.L. (2009) Building strong brands in a modern marketing communications environment. Journal of Marketing Communications 15 (2-3), 139-155.

Keller, K.L (2003) Brand Synthesis: The multidimensionality of brand knowledge. Journal of Consumer Research 29 (4), 595-600.

Keller, K.L. (2001). Building customer-based brand equity, Marketing Management 10 (2), 15-19.

Keller, K. L. (1993). Conceptualizing, measuring, and managing customer-based brand equity, Journal of Marketing, 57 (1), 1-22.

Kent, R.J and Allen, C.T (1994) Competitive interference effects in consumer memory for advertising: The role of brand familiarity. Journal of Marketing 58 (3), pp. 97-105.

Kim, Y. (2001). The impact of brand equity and the company's reputation on revenues, Journal of Promotion Management 6 (1-2), 89-111.

Koschler, G. and Merz, J. (1995). Sport sponsorship in isolation versus its integration into classical advertising. R'Activ: A case study on the effectiveness of sport sponsorship. In: Seminar on Advertising, Sponsorship and Promotions: Understanding and Measuring the Effectiveness of Commercial Communication, 15 - 17 March. Madrid, Spain, ESOMAR, 105124.

Kotler, P. (2003). Marketing Management. 11th ed., New Jersey, Pearson.

Lavidge, R.J. and Steiner, G.A. (1961) A model for predictive measurements of advertising effectiveness. Journal of Marketing, 25 (6) 59-62.

Levin, A. M., Beasley, F. and Gamble, T. (2004). Brand loyalty of NASCAR fans towards sponsors: The impact of fan identification. International Journal of Sports Marketing \& Sponsorship, 6 (1), 11-21.

Lough, N.L and Irwin, R.L (2001) A comparative analysis of sponsorship objectives for US Women's sport and traditional sport sponsorship. Sport Marketing Quarterly, 10 (4) pp.202211.

Martensen, A., Grønholt, L., Bendtsen, L. and Jensen, M.J. (2007). Application of a model for the effectiveness of event marketing, Journal of Advertising Research 47 (3), 283-301. 
Mason, R.B. and Cochetel, F. (2006). Residual brand awareness following the termination of a long-term event sponsorship and the appointment of a new sponsor, Journal of Marketing Communications 12 (2), 125-144.

McCarthy, M.S. and Fram, E.H. (2008). Synergies of promotional products and print advertising in building brand equity for a new brand, Journal of Promotion Management 14 $(1-2), 3-15$.

McCracken, G. (1989) Who is the celebrity endorser? Cultural foundations of the endorsement process. Journal of Consumer Research, 16 (3), 310-321.

Meenaghan, T. (1998). Current developments and future directions in sponsorship. International Journal of Advertising, 17 (1), 3-28.

Meenaghan, T. (1999). Commercial sponsorship - the development of understanding. International Journal of Sports Marketing \& Sponsorship, 1 (1), 19-31.

Meerabeau, E., Gillett, R., Kennedy, M, Adeoba, J, Byass, M and Tabi, K. (1991). Sponsorship and the drinks industry in the 1990s. European Journal of Marketing, 25 (11), 39-56.

Micu, A.C. and Thorson, E. (2008). Leveraging news and advertising to introduce new brands on the web, Journal of Interactive Advertising 9 (1), 14-26.

Nufer, G. and Bühler, A. (2010). How effective is the sponsorship of global sports events? A comparison of the FIFA World Cups in 2006 and 1998, International Journal of Sports Marketing \& Sponsorship 11 (4), 303-319.

Papadimitriou, D. and Apostolopoulou, A. (2009). Olympic sponsorship activation and the creation of competitive advantage, Journal of Promotion Management 15 (1/2), 90-117.

Pham, M. T. and Johar, G. V. (2001). Market prominence biases in sponsor identification: Processes and consequentiality. Psychology \& Marketing, 18 (2), 123-143.

Phelps, J. and Thorson, E. (1991) Brand familiarity and product involvement effects on the attitude towards and ad - brand attitude relationship. Advances in Consumer Research, 18 (1), 202-209.

Phillips, T.M. (2009). Does social desirability bias distort results on the Ego Identity Process Questionnaire or the Identity Style Inventory? Identity: An International Journal of Theory and Research 9 (1), 87-94.

Pope, N., Voges, K.E. and Brown, M. (2009). Winning Ways. Immediate and long-term effects of sponsorship on perceptions of brand quality and corporate image, Journal of Advertising 38 (2), 5-20.

Reuters (2011) Global sponsorship spending to rise 5.2 pct in 2011, Available at: http://www.reuters.com/article/idUSN1125970320110111 [Accessed 14 January 2011]. 
Rines, S. (2002). Guinness Rugby World Cup sponsorship: A global platform for meeting business objectives. International Journal of Sports Marketing \& Sponsorship, 3 (4), 449465 .

Roy, D. P. and Cornwell, T. B. (2004). The effects of consumer knowledge on responses to event sponsorships. Psychology \& Marketing, 21 (3), 185-207.

Simmons, C.J. and Becker-Olsen, K.L. (2006). Achieving marketing objectives through social sponsorship, Journal of Marketing 70 (4), 154-169.

Skildum-Reid, K., (2003). Last Generation Sponsorship. Available at:

http://www.powersponsorshipdownloads.com/powersponsorship/LastGenerationSponsorship. pdf [Date accessed: 25.01.10]

Smith, G. (2004). Brand image transfer through sponsorship: A consumer learning perspective. Journal of Marketing Management, 20 (3/4), 457-474.

Söderman, S. and Dolles, H. (2008). Strategic fit in international sponsorship - the case of the Olympic Games in Beijing 2008, International Journal of Sports Marketing \& Sponsorship 9 (2), 95-110.

Speed, R. and Thompson, P. (2000). Determinants of sports sponsorship response. Journal of the academy of marketing science, $\mathbf{2 8}$ (2), 226-238.

Thwaites, D. (1994). Corporate sponsorship by the financial services industry. Journal of Marketing Management, 10 (8), 743-763.

Thwaites, D. (1993). Sports sponsorship: Philanthropy or a commercial investment? Evidence from UK building societies. Journal of Promotion Management, 2 (1), 27-43.

Tomasini, N., Frye, C. \& Stotlar, D. (2004) National Collegiate Athletic Association Corporate Sponsor Objectives: Are There Differences Between Divisions I-A, I-AA, and IAAA? Sport Marketing Quarterly 13 (4), 216-226.

Too, L. H. Y., Souchon, A. L. and Thirkell, P. C. (2001) Relationship marketing and customer loyalty in a retail setting: A dyadic exploration. Journal of Marketing Management, 17 (3/4), 287-319.

Ukman, L. (2004). IEG's guide to sponsorship Chicago, IEG.

Viosca, R.C., Bergiel, B.J. and Balsmeier, P. (2005). Country Equity, Journal of Promotion Management 12 (1), 85-95.

Washburn, J. H. and Plank, R. E. (2002). Measuring brand equity: An evaluation of a consumer-based brand equity scale. Journal of Marketing Theory and Practice, 10 (1), 46-61.

Weeks, C.S., Cornwell, T.B. and Drennan, J.C. (2008). Leveraging sponsorship on the Internet: activation, congruence and articulation, Psychology \& Marketing 25 (7), 637-654. 
Wilson, M. and Sapsford, R. (1996) Asking Questions. In: Sapsford R. and Jupp, V. (eds.). Data Collection and Analysis. London, Sage, 94-120. 
Table 1: Consumer-Based Brand Equity Variables (Question wording)

\begin{tabular}{|c|c|c|c|}
\hline Brand Awareness & Brand Associations & Perceived Quality & Brand Loyalty \\
\hline $\begin{array}{l}\text { Brand recognition: Have you } \\
\text { heard of [Brand] }\end{array}$ & I trust $[$ Sponsor] & [Sponsor] is of high quality & I feel loyal to [Sponsor] \\
\hline $\begin{array}{l}\text { Product associations: What } \\
\text { specific products/services do } \\
\text { you associate with [Brand]? }\end{array}$ & $\begin{array}{l}\text { There are definite reasons to buy } \\
\text { products/services from [Sponsor] } \\
\text { rather than other providers }\end{array}$ & $\begin{array}{l}\text { Compared to other brands of } \\
\text { financial services, [Sponsor] is [ } 5 \\
\text { point scale from 'the best' to 'the } \\
\text { worst' plus 'don't know' option] }\end{array}$ & $\begin{array}{l}\text { I was satisfied with [Sponsor] the } \\
\text { last time I purchased a product or } \\
\text { service from the company }\end{array}$ \\
\hline \multirow[t]{4}{*}{$\begin{array}{l}\text { Brand opinion: I have an } \\
\text { opinion about [Brand] }\end{array}$} & $\begin{array}{l}\text { [Sponsor] is different from other } \\
\text { brands of financial services }\end{array}$ & $\begin{array}{l}\text { [Sponsor] is a leader in financial } \\
\text { services }\end{array}$ & $\begin{array}{l}\text { I intend to purchase } \\
\text { products/services from [Sponsor] } \\
\text { in the future }\end{array}$ \\
\hline & $\begin{array}{l}\text { The [Sponsor] brand has a } \\
\text { distinctive personality }\end{array}$ & $\begin{array}{l}\text { [Sponsor] is a brand that is growing } \\
\text { in popularity }\end{array}$ & $\begin{array}{l}\text { I would recommend [Sponsor] to } \\
\text { my friends and family }\end{array}$ \\
\hline & $\begin{array}{l}\text { [Sponsor] offers worse value for } \\
\text { money than other brands }\end{array}$ & $\begin{array}{l}\text { [Sponsor] offers innovative products } \\
\text { and services }\end{array}$ & $\begin{array}{l}\text { When I am looking for a financial } \\
\text { services provider, I will consider } \\
\text { [Sponsor] }\end{array}$ \\
\hline & $\begin{array}{l}\text { I have a clear image of the type of } \\
\text { person who would use [Sponsor's] } \\
\text { products/services }\end{array}$ & [Sponsor] is a brand I respect & $\begin{array}{l}\text { I would be willing to pay a higher } \\
\text { price for [Sponsor] } \\
\text { products/services over other } \\
\text { competing brands }\end{array}$ \\
\hline
\end{tabular}


Table 2: Demographic Data

\begin{tabular}{|c|c|c|c|c|}
\hline & \multicolumn{2}{|c|}{ New Brand Sponsorship } & \multicolumn{2}{|c|}{ Established Brand Sponsorship } \\
\hline & Event-based sample (\%) & Comparison sample (\%) & Event-based sample (\%) & Comparison sample (\%) \\
\hline Gender & $n=114$ & $n=280$ & $n=205$ & $n=141$ \\
\hline Male & 45.6 & 55.4 & 50.7 & 61.7 \\
\hline \multirow{2}{*}{ Female } & 54.4 & 44.6 & 49.3 & 38.3 \\
\hline & \multicolumn{2}{|c|}{$\chi^{2}(1)=3.084, p<0.10$} & \multicolumn{2}{|c|}{$\chi^{2}(1)=4.066, p<0.05^{*}$} \\
\hline Age & $n=114$ & $n=280$ & $n=205$ & $n=141$ \\
\hline $18-24$ & 0.0 & 10.0 & 8.8 & 15.6 \\
\hline $25-34$ & 0.0 & 9.3 & 20.0 & 9.9 \\
\hline $35-44$ & 2.6 & 19.3 & 22.4 & 15.6 \\
\hline $45-54$ & 1.8 & 27.9 & 17.6 & 33.3 \\
\hline $55-64$ & 30.7 & 19.3 & 22.9 & 18.4 \\
\hline \multirow[t]{2}{*}{$65+$} & 64.9 & 14.3 & 8.3 & 7.1 \\
\hline & \multicolumn{2}{|c|}{$\chi^{2}(5)=141.143, \mathrm{p}<0.05^{*}$} & \multicolumn{2}{|c|}{$\chi^{2}(5)=20.295, \mathrm{p}<0.05^{*}$} \\
\hline Income & $n=55$ & $n=242$ & $n=168$ & $n=114$ \\
\hline Less than $£ 10000$ & 16.4 & 6.2 & 8.9 & 6.1 \\
\hline$£ 10001-£ 20000$ & 30.9 & 12.4 & 14.3 & 11.4 \\
\hline$£ 20001-£ 30000$ & 21.8 & 21.5 & 20.8 & 19.3 \\
\hline$£ 30001-£ 40000$ & 16.4 & 17.8 & 24.4 & 12.3 \\
\hline$£ 40001-£ 50000$ & 9.1 & 12.8 & 12.5 & 14.0 \\
\hline \multirow[t]{2}{*}{ More than $£ 50001$} & 5.5 & 29.3 & 19.0 & 36.8 \\
\hline & \multicolumn{2}{|c|}{$\chi^{2}(5)=26.261, p<0.05^{*}$} & \multicolumn{2}{|c|}{$\chi^{2}(5)=14.622, p<0.05^{*}$} \\
\hline
\end{tabular}

*significant at $\mathrm{p}<0.05$ 
Table 3: Mean Brand Equity Dimensions Scores (New Brand Sponsor)

\begin{tabular}{|l|l|l|l|}
\hline $\begin{array}{l}\text { Sample } \\
\text { Group }\end{array}$ & Brand Associations & Perceived Quality & Brand Loyalty \\
\hline Event & $1.33(\mathrm{n}=103)$ & $1.22(\mathrm{n}=102)$ & $0.84(\mathrm{n}=104)$ \\
\hline Comparison & $1.21(\mathrm{n}=14)$ & $0.64(\mathrm{n}=14)$ & $-0.33(\mathrm{n}=12)$ \\
\hline & $\mathrm{t}=0.12, \mathrm{p}=0.90$ & $\mathrm{t}=0.75, \mathrm{p}=0.47$ & $\mathrm{t}=1.00, \mathrm{p}=0.34$ \\
\hline
\end{tabular}


Table 4: Mean Individual Brand Equity Element Scores (New Brand Sponsor)

\begin{tabular}{|c|c|c|c|}
\hline Attribute & Event-based sample & Comparison sample & \\
\hline \multicolumn{4}{|l|}{ Brand Associations } \\
\hline Trust & $0.34(n=108)$ & $0.21 \quad(n=14)$ & $\mathrm{t}=0.75, \mathrm{p}=0.47$ \\
\hline Differentiation & $0.25(\mathrm{n}=110)$ & $0.50 \quad(n=14)$ & $\mathrm{t}=-1.20, \mathrm{p}=0.25$ \\
\hline Reasons to purchase & $0.19(n=109)$ & $0.21 \quad(n=14)$ & $\mathrm{t}=-0.09, \mathrm{p}=0.93$ \\
\hline Distinctive personality & $0.25(n=109)$ & $0.21(n=14)$ & $\mathrm{t}=0.14, \mathrm{p}=0.89$ \\
\hline Value for money** & $0.18(n=111)$ & $0.00(n=14)$ & $\mathrm{t}=0.94, \mathrm{p}=0.36$ \\
\hline User image & $0.24(\mathrm{n}=111)$ & $0.07(\mathrm{n}=14)$ & $\mathrm{t}=0.98, \mathrm{p}=0.34$ \\
\hline \multicolumn{4}{|l|}{ Perceived Quality } \\
\hline High quality & $0.36(\mathrm{n}=110)$ & $0.21 \quad(n=14)$ & $\mathrm{t}=0.60, \mathrm{p}=0.56$ \\
\hline Respect & $0.32(n=110)$ & $0.21 \quad(n=14)$ & $\mathrm{t}=0.41, \mathrm{p}=0.69$ \\
\hline Leadership & $0.27(n=108)$ & $-0.14(n=14)$ & $\mathrm{t}=1.91, \mathrm{p}=0.08$ \\
\hline Growing in popularity & $0.30(\mathrm{n}=110)$ & $0.36(\mathrm{n}=14)$ & $\mathrm{t}=-0.31, \mathrm{p}=0.76$ \\
\hline Innovation & $0.18(n=111)$ & $0.00(n=14)$ & $\mathrm{t}=1.14, \mathrm{p}=0.27$ \\
\hline Comparison with competitors & $0.27(\mathrm{n}=108)$ & $-0.14(n=14)$ & $\mathrm{t}=2.65, \mathrm{p}=0.02 *$ \\
\hline \multicolumn{4}{|l|}{ Brand Loyalty } \\
\hline Expressed loyalty & $0.22(n=110)$ & $-0.08(n=13)$ & $\mathrm{t}=1.19, \mathrm{p}=0.26$ \\
\hline Satisfaction with previous purchase & $0.10(\mathrm{n}=108)$ & $0.14(n=14)$ & $\mathrm{t}=-0.28, \mathrm{p}=0.79$ \\
\hline Recommendation to friends/family & $0.23(\mathrm{n}=106)$ & $0.00(n=13)$ & $\mathrm{t}=0.97, \mathrm{p}=0.35$ \\
\hline Purchase intention & $0.21(\mathrm{n}=112)$ & $-0.07(n=14)$ & $\mathrm{t}=1.06, \mathrm{p}=0.31$ \\
\hline Willingness to pay price premium & $0.14(n=111)$ & $-0.36(n=14)$ & $\mathrm{t}=1.58, \mathrm{p}=0.14$ \\
\hline Consideration & $0.22(n=110)$ & $-0.07(n=14)$ & $\mathrm{t}=0.84, \mathrm{p}=0.42$ \\
\hline
\end{tabular}

*significant at $\mathrm{p}<0.05$

** Reverse scored to reflect negative wording of statement 
Table 5: Mean Brand Equity Dimensions Scores (Established Brand Sponsor)

\begin{tabular}{|l|l|l|l|}
\hline $\begin{array}{l}\text { Sample } \\
\text { Group }\end{array}$ & Brand Associations & Perceived Quality & Brand Loyalty \\
\hline Event & $5.75(\mathrm{n}=194)$ & $7.31(\mathrm{n}=191)$ & $4.85(\mathrm{n}=196)$ \\
\hline Comparison & $4.00(\mathrm{n}=133)$ & $6.26(\mathrm{n}=136)$ & $3.36(\mathrm{n}=136)$ \\
\hline & $\mathrm{t}=4.06, \mathrm{p}=0.00^{*}$ & $\mathrm{t}=2.43, \mathrm{p}=0.02^{*}$ & $\mathrm{t}=2.97, \mathrm{p}=0.00^{*}$ \\
\hline
\end{tabular}


Table 6: Mean Individual Brand Equity Element Scores (Established Brand Sponsor)

\begin{tabular}{|c|c|c|c|}
\hline Attribute & Event-based sample & Comparison sample & \\
\hline \multicolumn{4}{|l|}{ Brand Associations } \\
\hline Trust & $1.13(n=203)$ & $1.30(\mathrm{n}=138)$ & $\mathrm{t}=0.08, \mathrm{p}=0.93$ \\
\hline Differentiation & $0.69(\mathrm{n}=199)$ & $0.38(\mathrm{n}=136)$ & $\mathrm{t}=2.87, \mathrm{p}=0.00^{*}$ \\
\hline Reasons to purchase & $0.86(n=202)$ & $0.61 \quad(n=137)$ & $\mathrm{t}=2.19, \mathrm{p}=0.03^{*}$ \\
\hline Distinctive personality & $1.12(n=200)$ & $0.74(n=137)$ & $\mathrm{t}=3.32, \mathrm{p}=0.00^{*}$ \\
\hline Value for money** & $1.00(n=202)$ & $0.79(n=136)$ & $\mathrm{t}=2.20, \mathrm{p}=0.03^{*}$ \\
\hline User image & $0.73(n=201)$ & $0.25(n=138)$ & $\mathrm{t}=4.31, \mathrm{p}=0.00^{*}$ \\
\hline \multicolumn{4}{|l|}{ Perceived Quality } \\
\hline High quality & $1.44(n=202)$ & $1.48(\mathrm{n}=138)$ & $\mathrm{t}=-0.39, \mathrm{p}=0.70$ \\
\hline Respect & $1.42 \quad(\mathrm{n}=202)$ & $1.41(\mathrm{n}=138)$ & $\mathrm{t}=0.10, \mathrm{p}=0.92$ \\
\hline Leadership & $1.23(\mathrm{n}=199)$ & $0.90(\mathrm{n}=137)$ & $\mathrm{t}=2.94, \mathrm{p}=0.00^{*}$ \\
\hline Growing in popularity & $1.12(\mathrm{n}=201)$ & $0.84(\mathrm{n}=137)$ & $\mathrm{t}=3.17, \mathrm{p}=0.00^{*}$ \\
\hline Innovation & $0.90 \quad(n=2010$ & $0.70(n=138)$ & $\mathrm{t}=2.31, \mathrm{p}=0.02 *$ \\
\hline Comparison with competitors & $1.10(n=198)$ & $0.94(n=137)$ & $\mathrm{t}=1.66, \mathrm{p}=0.10$ \\
\hline \multicolumn{4}{|l|}{ Brand Loyalty } \\
\hline Expressed loyalty & $0.70(n=200)$ & $0.21 \quad(n=138)$ & $\mathrm{t}=3.74, \mathrm{p}=0.00^{*}$ \\
\hline Satisfaction with previous purchase & $1.11(n=200)$ & $1.19(\mathrm{n}=137)$ & $\mathrm{t}=-0.71, \mathrm{p}=0.48$ \\
\hline Recommendation to friends/family & $0.92(n=201)$ & $0.83(n=137)$ & $\mathrm{t}=0.72, \mathrm{p}=0.47$ \\
\hline Purchase intention & $0.82(n=201)$ & $0.46(n=138)$ & $\mathrm{t}=3.09, \mathrm{p}=0.00^{*}$ \\
\hline Willingness to pay price premium & $-0.18(n=201)$ & $-0.66(n=137)$ & $\mathrm{t}=3.75, \mathrm{p}=0.00^{*}$ \\
\hline Consideration & $1.47(n=202)$ & $1.33(\mathrm{n}=138)$ & $\mathrm{T}=1.20, \mathrm{p}=0.23$ \\
\hline
\end{tabular}

*significant at $\mathrm{p}<0.05$

** Reverse scored to reflect negative wording of statement 